\title{
Pengaruh Pemberian Kombinasi Rumput Alam, Lamtoro dan Daun Turi Terhadap Konsumsi Ransum, PBBH dan Konversi Pakan pada Ternak Kambing Kacang Betina Lokal
}

\author{
Anna Handriana Luruk ${ }^{\mathrm{a}}$ \\ ${ }^{a}$ Fakultas Pertanian, Universitas Timor, Kefamenanu, TTU - NTT, 85613, Indonesia
}

\section{Article Info}

Article history:

Received 20 Januari 2016

Received in revised form 15 Februari 2016

Accepted 23 Maret 2016

Keywords :

Ransum

Ransum

Konversi Pakan

Kambing Kacang

\section{Pendahuluan}

Ternak kambing adalah salah satu komoditi yang memiliki prospek yang cukup baik untuk dikembangkan bila dibandingkan dengan ternak ruminansia besar, karena ternak kambing dengan sifat yang cocok dibudidayakan di daerah pedesaan yang sebagian besar penduduknya adalah petani penghasilan rendah. Ternak kambing juga dikenal oleh masyarakat dan memegang peranan penting dalam perekonomian masyarakat pedesaan karena pada umumnya usaha pemeliharaan ternak kambing dilakukan di daerah pedesaan dan tidak dapat dipisahkan dari usahatani di Indonesia.

Ternak kambing merupakan ternak ruminansia kecil yang dalam pemeliharaannya mudah dilakukan, modal dan resiko kerugiannya sangat kecil bila dibandingkan dengan ternak ruminansia besar. Ternak kambing juga mempunyai peranan yang cukup penting dalam rangka memenuhi kebutuhan hewani bagi masyarakat. Namun demikian usaha ternak kambing pada umumnya masih dilakukan petani peternak sebagai usaha sampingan atau tambahan untuk memenuhi kebutuhan keluarga dengan pemeliharaan yang masih sederhana atau tradisional.

Hijauan di daerah tropis tumbuh dengan cepat namun kualitasnya yang diperoleh pada umumnya serta kontinuitasnya juga terbatas. Hal ini terjadi karena pada musim hujan ketersediaan hijauan melimpah bahkan banyak yang tidak maksimal dapat dimanfaatkan karena terbatasnya pengetahuan tentang aplikasi teknologi pada tingkat peternak. Sebaliknya pada musim kemarau yang biasanya berlangsung selama 8-9 bulan per tahun menyebabkan terjadinya penurunan kualitas, kuantitas dan kontiniutas hijauan pakan ternak (Devendra dan Burns, 1996).

Sarwono (1991) mendefinisikan bahwa, pakan adalah semua bahan makanan yang penting bagi ternak sebagai sarana pembina pertumbuhan tubuh. Sebab tubuh membutuhkan bahan pembangun yang berasal dari pakan yang sempurna. Oleh karena itu, pakan yang sempurna mengandung protein, karbohidrat, lemak, air, vitamin, BETN dan mineral. Menurut Anggorodi (1994), umumnya bahan makanan ternak terdiri dari bahan-bahan yang berasal dari tanaman-tanaman terutama sisa-sisa hasil ikutan dari berbagai pabrik dan perusahaan.

Umumnya bahan makanan ternak tersebut terdiri dari tanaman-tanaman yaitu rumput alam, lamtoro dan turi. Susetyo (1969) menyatakan bahwa, tanaman lamtoro (Laucaena leucocephala) berbentuk pohon mencapai ketinggian 10-50 $\mathrm{m}$ dan memiliki sistem perakaran yang cukup dalam, daun kecil-kecil, bentuk lonjong sedangkan bunganya bertangkai dan warnanya kekuningan. Daun tanaman lamtoro untuk makanan ternak kambing dan memiliki protein yang tinggi dan diberikan dalam bentuk segar juga diberikan dalam bentuk campur dengan bahan pakan yang lain untuk melengkapi protein dan energi.

Tanaman turi (Sesbania grandiflora) berbentuk pohon termasuk jenis kacang-kacangan. Hijauan turi yang digunakan sebagai pakan ternak sanga menguntungkan karena merupakan sumber protein mineral terutama cadangan pakan. Salah satu jenis pohon legume yang sangat baik untuk diberikan pada ternak ruminansia adalah daun turi dimana kandungan proteinnya cukup baik yakni 18,8\%, sedangkan kandungan lemak sebesar 4,80\% (Soeyanto, 1981).

Dengan keadaan yang demikian ini, maka keberadaan rumput alam, daun lamtoro dan turi yang cukup tersedia dan mengandung nilai protein yang tinggi dapat dijadikan sebagai bahan pakan untuk meningkatkan konsumsi dan pertambahan bobot badan ternak kambing.

Penelitian ini bertujuan untuk mengetahui pengaruh pemberian kombinasi rumput alam, lamtoro dan daun turi terhadap konsumsi ransum, $\mathrm{PBBH}$ dan konversi pakan pada ternak kambing kacang betina lokal.

\section{Metode}

2.1 Waktu dan Tempat

Penelitian dilaksanakan di Desa Inbate, Kecamatan Bikomi Nilulat, Kabupaten Timur Tengah Utara yang berlangsung selama dua bulan dari bulan Juni 2015 sampai Agustus 2015.

\subsection{Materi Penelitian}

Ternak yang digunakan adalah ternak kambing kacang betina lokal sebanyak 16 ekor dengan kisaran umur rata-rata 6-9 bulan, kisaran berat badan awal 10-21 kg. Penentuan umur ternak didasarkan pada rumus pergantian gigi.

Ransum yang diberikan pada ternak terdiri dari rumput alam, lamtoro dan turi yang diperoleh di sekitar lokasi penelitian. Kandang yang digunakan adalah kandang tipe individu terdiri dari 16 petak dan dibagi dalam empat blok dimana setiap blok terdiri dari empat petak kandang berukuran $50 \mathrm{~cm} \times 1 \mathrm{~m}^{2}$. Tiap petaknya dilengkapi tempat makan dan minum.

\subsection{Rancangan Percobaan}

Rancangan yang digunakan adalah Rancangan Acak Kelompok (RAK) dengan empat perlakuan dan empat ulangan. Perlakuan yang diuji terdiri dari $\mathrm{r}_{0}$ (100\% rumput alam), $\mathrm{r}_{1}$ (40\% rumput alam, 30\% Lamtoro, $30 \%$ daun turi), $\mathrm{r}_{2}$ (30\% rumput alam, 35\% Lamtoro, 35\% daun turi), $\mathrm{r}_{3}$ (20\% rumput alam, $40 \%$ Lamtoro, $40 \%$ daun turi).

\subsection{Tahapan Penelitian}

Tahap-tahap yang dilakukan dalam penelitian ini adalah 1) Melakukan pembuatan kandang; 2) Menempatkan ternak ke dalam kandang sesuai dengan hasil pengacakan; 3) Memberikan ransum yang telah disusun pada ternak sesuai hasil pengacakan ternak terhadap perlakuan; 4) Melakukan penimbangan pakan yang diberikan maupun sisa pakan yang tidak habis terkonsumsi; 5) Melakukan penimbangan berat badan ternak setiap minggu; dan 6) Melakukan pengolahan data konsumsi ransum, PBBH dan konversi pakan.

\subsection{Variabel Penelitian}

Variabel yang diamati dalam penelitian ini adalah konsumsi ransum, pertambahan bobot badan dan konversi ransum. Konsumsi ransum diperoleh dari hasil pengurangan jumlah ransum yang diberikan dengan ransum yang sisa atau tidak dikonsumsi (g/ekor/hari). Pertambahan bobot badan diperoleh dari berat badan akhir dikurangi berat badan awal ternak kemudian dibagi dengan lamanya waktu penelitian (kg/ekor/hari). Konversi pakan (\%) diperoleh dengan membagi jumlah pakan yang dikonsumsi dengan pertambahan bobot badan harian dengan satuan berat yang sama.

\subsection{Analisis Data}

Data yang diperoleh dianalisis berdasarkan prosedur statistik Rancangan Acak Kelompok dan apabila terdapat perbedaan perlakuan maka dilanjutkan dengan uji Duncan untuk mengetahui perbandingan antara ransum perlakuan sesuai dengan petunjuk Steel dan Torrie (1993).

\section{Hasil dan Pembahasan}

3.1 Keadaan Umum

Ternak kambing yang digunakan di ambil dari petani peternak dalam wilayah Kecamatan Bikomi Nilulat Desa Inbate. Secara umum semua ternak (16 ekor) dalam keadaan sehat dan normal serta tidak cacat fisik maupun bentuk tubuhnya, yang ditandai dengan tingkah laku makan dalam mengkonsumsi pakan yang yang diberikan. Pemberian ransum perlakuan dilakukan dua kali sehari yakni pagi dan sore hari.

\subsection{Pengaruh Perlakuan Terhadap Konsumsi Ransum}

Rata-rata konsumsi ransum selama penelitian disajikan pada Tabel 1 . Terlihat bahwa rata-rata konsumsi makanan tertinggi terdapat pada ternak percobaan yang mendapat perlakuan $r_{3}$ yaitu sebesar 8021,835 gram/minggu dan diikuti oleh $r_{2}$ sebesar 7594,322 gram/minggu, $r_{1}$ sebesar 7326,412 gram/minggu dan $r_{0}$ sebesar 6355,312 gram/minggu.

Hasil sidik ragam menunjukkan bahwa perlakuan berpengaruh sangat nyata $(\mathrm{P}<0,01)$ terhadap konsumsi ransum. Hasil uji lanjut (Duncan) mengindikas bahwa ransum perlakuan $r_{3}$ yang tersusun dari rumput alam $(20 \%)$, lamtoro $(40 \%)$ dan turi $(40 \%)$ lebih baik dengan ransum perlakuan lainnya. Perlakuan 
berpengaruh sangat nyata terhadap variabel yang diteliti ini disebabkan kondisi fisik dari ternak dan kemampuan palatabilitas dari ternak dalam mengkonsumsi ransum perlakuan, serta tergantung pada kandungan nutrisi yang terkandung dalam bahan pakan. Menurut Parakasi (2000), tingkat gizi pakan mempengaruhi palatabilitas atau suka tidaknya ternak terhadap bahan pakan yang diberikan.

Tabel 1. Rata-Rata Konsumsi Ransum Ternak (Gram/Ekor/Minggu)

\begin{tabular}{|c|c|c|c|c|c|c|}
\hline \multirow{2}{*}{ Perlakuan } & \multicolumn{4}{|c|}{ Ulangan } & \multirow{2}{*}{ Total } & \multirow{2}{*}{ Rataan } \\
\hline & $\mathrm{I}$ & II & III & IV & & \\
\hline $\mathrm{r}_{0}$ & 3929 & 5313 & 7420 & 8758 & 25421 & 6355 \\
\hline $\mathrm{r}_{1}$ & 4899 & 7368 & 8187 & 8849 & 29305 & 7326 \\
\hline$r_{2}$ & 5575 & 7512 & 8193 & 9095 & 30377 & 7594 \\
\hline $\mathrm{r}_{3}$ & 6078 & 7927 & 8900 & 9180 & 32087 & 8021 \\
\hline Total & 20483 & 28122 & 32701 & 35883 & 117191 & \\
\hline Rataan & 5120 & 7030 & 8175 & 8970 & & \\
\hline
\end{tabular}

Menurut Tilman (1989), salah satu faktor utama penghambat dalam pakan yaitu adanya partisipasi yang sangat besar dari efek fisik pakan dalam saluran pencernaan yang bersifat volumius (Bulky), misalnya kandungan serat kasar dalam jumlah yang besar dalam pakan yang dapat menyebabkan pembatasan tingkat kesukaan oleh ternak kambing.

Konsumsi pakan dapat dikendalikan oleh dua faktor yaitu yaitu1) palatabilitas yakni jumlah konsumsi pakan pada ternak lebih tinggi disebabkan baik dari segi kuantitas maupun kualitas sangat bagus; 2) laju pengosongan lambung yaitu gerak laju bahan makanan dalam saluran pencernaan membutuhkan waktu untuk mengosongkan lambung tergantung pada umur ternak. Cepat lambatnya pengosongan lambung dari bahan makan yang terisi tergantung pada kapasitas tampung lambung dari ternak (Tilman, 1989).

\subsection{Pengaruh Perlakuan Terhadap Pertambahan Bobot Badan}

Rata-rata pertambahan berat badan ternak disajikan pada Tabel 2. Ratarata pertambahan berat badan tertinggi pada ternak yang mendapat perlakuan $r_{3}$ yakni rumput alam 20\%, lamtoro $40 \%$ dan turi $40 \%$ yaitu sebesar 243,17 gram/minggu diikuti oleh ternak yang mendapat perlakuan $r_{2}$ yakni rumput alam $30 \%$, lamtoro $35 \%$ dan turi $35 \%$ yaitu sebesar 233,98 gram/minggu, kemudian yang mendapat perlakuan $\mathrm{r}_{1}$ yakni rumput alam $40 \%$, lamtoro $30 \%$ dan turi $30 \%$ yaitu sebesar 220,16 gram/minggu dan tanpa perlakuan atau $\mathbf{r}_{0}$ yakni rumput alam $100 \%$ yaitu sebesar 207,32 gram/minggu.

Tabel 2. Rata-Rata Pertambahan Bobot Badan (Gram/Ekor/Minggu)

\begin{tabular}{|c|c|c|c|c|c|c|}
\hline \multirow{2}{*}{ Perlakuan } & \multicolumn{4}{|c|}{ Ulangan } & \multirow{2}{*}{ Total } & \multirow{2}{*}{ Rataan } \\
\hline & I & II & III & IV & & \\
\hline $\mathrm{r}_{0}$ & 139,52 & 231,82 & 240,68 & 269,68 & 881,28 & 207,32 \\
\hline $\mathrm{r}_{1}$ & 164,92 & 204,12 & 205,31 & 254,28 & 828,65 & 220,16 \\
\hline$r_{2}$ & 192,69 & 215,95 & 241,58 & 285,71 & 935,95 & 233,98 \\
\hline$r_{3}$ & 267,46 & 203,80 & 230,31 & 271,11 & 972,69 & 243,17 \\
\hline Total & 764,60 & 855,71 & 917,47 & 1080,79 & 3618,58 & \\
\hline Rataan & 191,15 & 213,92 & 229,36 & 270,19 & & \\
\hline
\end{tabular}

Hasil analisis keragaman menunjukkan bahwa perlakuan berpengaruh sangat nyata $(\mathrm{P}<0,01)$ terdapat pertambahan berat badan ternak kambing. Uji lanjut Duncan di peroleh hasil perlakuan $r_{3}-r_{0}, \quad r_{2}-r_{0}, \quad r_{3}-r_{1}, \quad r_{2}-r_{1}, \quad r_{3}-r_{2}$ menunjukkan perbedaan sangat nyata $(P<0,01)$. Sedangkan untuk perlakuan $r_{1}-$ $\mathrm{r}_{0}$ menunjukan perbedaan yang tidak nyata. Dengan demikian pemberian hijauan berpengaruh positif terhadap pertumbuhan ternak kambing karena pertumbuhan sebagai proses perbanyakan atau pertambahan jumlah sel yang disebut hyperplasia dan penambahan ukuran sel yang disebut hypertrophy yang diikuti oleh pertumbuhan berat badan dan perkembangan ukuran tubuh.

Nazzaruddin dan Viviana (1991) menyatakan bahwa pada umumnya semua ternak kambing dapat digemukan akan tetapi yang mencapai optimal adalah ternak kambing yang mempunyai pertumbuhan yang lebih cepat, untuk mendapat pertambahan berat badan yang efisien perlu meningkatkan kandungan energi dalam pakan yang erat hubungannya dengan protein pakan, sehingga dengan kandungan zat-zat tersebut, maka ternak yang dipelihara pertumbuhan dan produksi dapat ditingkatkan. Oleh karena itu pakan yang diberikan dapat dibagi menjadi bagian yang diperlukan untuk pemeliharaan tubuh dan juga untuk produksi.

Menurut Anggorodi (1985), pertumbuhan mencakup pertambahan dalam bentuk dan berat jaringan-jaringan pembangun seperti urat, daging, tulang, jantung, otak dan semua tubuh lainnya.

\subsection{Pengaruh Perlakuan Terhadap Konversi Pakan}

Rata-rata konversi pakan penggunaan ransum ternak penelitian disajikan pada Tabel 3. Rata-rata konversi pakan penggunaan ransum tertinggi ditunjukkan oleh ternak yang mendapat perlakuan $r_{3}$ yaitu sebesar 7,33, kemudian diikuti oleh ternak yang mendapat perlakuan $r_{2}$ sebesar 4,61 dan kemudian $r_{1}$ sebesar 3,15 dan $r_{0}$ sebesar 2,66.

Hasil analisis keragaman menunjukkan bahwa perlakuan memberikan pengaruh sangat nyata $(P<0,01)$ terhadap konversi pakan penggunaan ransum ternak kambing. Uji lanjut Duncan menunjukan bahwa perbedaan yang sangat nyata $(\mathrm{P}<0,01)$ antara perlakuan $\mathrm{r}_{3}-\mathrm{r}_{0}, \mathrm{r}_{2}-\mathrm{r}_{0}, \mathrm{r}_{3}-\mathrm{r}_{1}, \mathrm{r}_{2}-\mathrm{r}_{1}, \mathrm{r}_{3}-\mathrm{r}_{2}$. Sedangkan $\mathrm{r}_{1}-\mathrm{r}_{0}$ menunjukkan perbedaan tidak nyata. Dengan demikian meningkatnya kecernaan bahan pakan yang dikonsumsi menyebabkan meningkatnya penyerapan zat-zat makanan hasil pencernaan yang dapat dipergunakan untuk fungsi biologik ternak (Pond dan Church, 2005). Kemungkinan ternak kambing mampu menggunakan ransum berfungsi memfermentasikan pakan berserat kasar tinggi dan rendah kadar nutriennya, sehingga tidak semuanya terbuang lewat feses tetapi separuhnya masih bermanfaat bagi pertumbuhan. Pertumbuhan itu sendiri merupakan proses pembesaran dan perbanyakan sel sehingga dengan semakin meningkatnya energi yang tersedia dalam pakan menyebabkan produksi meningkat termasuk pertambahan berat badan dan konversi pakan penggunaan ransum.

Tabel 3. Rata-Rata Konversi Pakan (\%)

\begin{tabular}{|c|c|c|c|c|c|c|}
\hline \multirow{2}{*}{ Perlakuan } & \multicolumn{4}{|c|}{ Ulangan } & \multirow{2}{*}{ Total } & \multirow{2}{*}{ Rataan } \\
\hline & I & II & III & IV & & \\
\hline $\mathrm{r}_{0}$ & 3,74 & 2,68 & 2,44 & 1,79 & 10,65 & 2,66 \\
\hline$r_{1}$ & 3,81 & 3,12 & 2,97 & 2,72 & 12,62 & 3,15 \\
\hline$r_{2}$ & 6,70 & 4,79 & 3,54 & 3,41 & 18,44 & 4,61 \\
\hline$r_{3}$ & 9,02 & 6,02 & 7,96 & 6,35 & 29,35 & 7,33 \\
\hline Total & 23,27 & 16,61 & 16,91 & 14,27 & 71,06 & \\
\hline Rataan & 5,81 & 4,15 & 4,22 & 3,56 & & \\
\hline
\end{tabular}

\section{Simpulan}

Pemberian konsumsi ransum rumput alam, lamtoro dan daun turi berpengaruh sangat nyata terhadap nilai konsumsi ransum percobaan $\left(r_{3}\right.$ 8021,83 g/ekor/minggu), pada variabel pertambahan bobot badan $\left(r_{3} 241,17\right.$ g/ekor/minggu) dan pada variabel konversi pakan $\left(r_{3} 7,33 \%\right)$. Pemberian $20 \%$ rumput alam, $40 \%$ lamtoro, $40 \%$ daun turi memberikan hasil terbaik terhadap semua variabel yang diuji cobakan.

\section{Pustaka}

Anggorodi. 1994. Ilmu Makanan Ternak. PT. Gramedia Pustaka Utama. Jakarta.

Anggorodi. 1985. Konsumsi Pakan Ternak Ruminansia. PT Gramedia Pustaka Utama. Jakarta.

Devandra dan Burns. 1996. Pemanfaaatan Ternak Kambing. PT Swadaya, Jakarta.

Nazzaruddin dan Viviana. 1991. Petunjuk Praktis Usaha Peternakan. PT Mahkota. Jakarta.

Pond dan church. 2005. Peranan Konversi Pakan Terhadap Pertambahan Bobot Badan dipropinsi Bengkulu. Jurnal Penelitian Universitas Bengkulu.

Parakasi. 2000. Ilmu Nutrisi dan Makanan Ternak Monogastrik. PT Angkasa Bandung.

Sarwano. 1991. Pakan Ternak Kambing dan Ilmu Nutrisi. PT Swadaya. Jakarta. Susetyo. 1969. Ilmu Makanan Ternak Kambing. PT Kanisius. Yogyakarta.

Soeyanto. 1981. Ilmu Makanan Ternak dan Ilmu Nutrisi. PT Swadaya. Jakarta.

Steel dan Torrie. 1993. Perlakuan Ransum dan Rancangan percobaan Praktis Bidang Pertaninan. Kanisius. Yogyakarta.

Tillman, A.D., Hari H., Soedomo R., Soeharto P., dan Sukato, L., 1989. Ilmu Makanan Ternak Dasar. UGM-Press, Yogyakarta. 